\title{
EFL Students' Ability to Identify Singular and Plural Nouns in Paragraph
}

\author{
Nurma Dhona Handayani \& Frangky Silitonga \\ Universitas Putera Batam \\ (nurmadhona@gmail.com \& frangkyka@gmail.com)
}

\begin{abstract}
This research aims to describe the ability of students to identify singular and plural nouns in the paragraph. The researchers use random sampling techniques to collect the data. Forty students at second semester of English Department in Putera Batam University are taken as the sample. In analyzing the data, researchers classify or categorize the ability of students into six levels: excellent, very good, good, fair, poor, and very poor. Based on the test results, it can be concluded that the ability of second semester students of English Department in Putera Batam University in identifying the singular and plural nouns in a paragraph is good. The results show that three students $(7.5 \%)$ are categorized as excellent, ten students or $25 \%$ are categorized as very good, eleven students (27.5\%) are categorized as good, six students (15\%) are categorized as fair, six students (15\%) are categorized as poor and four students (10\%) are categorized as very poor. Therefore, it can be concluded that the ability of students is good.
\end{abstract}

Keywords: singular, plural, paragraf.

English is one of important subjects by which EFL students in Indonesia learn it. In learning English, students should be mastered the four useful skills (listening, speaking, reading, and writing) for communication. They can use books, magazines, radio, TV, and internet to help them in daily activities and in their environment. Besides, grammar is also needed in helping the students to master all of those skills.

Grammar or structure is one of the aspects of language that should be learned by the students in order to be able to use English for communication in spoken and written forms. As we know, grammar is the basic of English. It is used in all aspects of English for instance in listening, speaking, reading, and writing.

Grammar, as one of the elements in English language, has an important role in the use of language. It is a description of the structure of the language and the way in which linguistic units such as word, phrases, and clauses are combined to produce sentences in the language. By following the rules, the pattern of the sentence can be identified and readers will easily understand the sentence. With grammar, words can be arranged to form some acceptable English sentences. It can be concluded that we should know English grammar in order to be able to use English.

Some students, however, do not have enough knowledge on grammar. They do not know how to express a good sentence. In other words, English should be expressed by understanding the element of the language itself. There are many elements of grammar for instances tenses, verbs, preposition, punctuation, nouns, etc. and one of the elements in grammar which is important to be considered during the English teaching 
and learning process is noun. The writer chose noun because based on short observation, the result of students who learned noun is still low. They get difficulties and confusion to determine and distinguish which one is noun of the paragraph, especially about plural and singular.

In addition, according to Djauhari (1988, p. 70), noun can be classified to three categorizations namely; (1) kinds, (2) types, and (3) numbers. One of them is numbers. Number of nouns is the noun that is decided from the quantity of noun. This is divided into two kinds, singular noun and plural noun. Unfortunately, most English learners still had difficulties to identify the usage of singular and plural nouns.

It is important for the students to identify between singular and plural noun. Based on the observation at the second semester students of English Department in Putera Batam University who have learned about Singular and Plural Nouns, it has been done several exercises related to Singular and Plural Nouns. So, it is assumed that they have good ability in singular and plural noun. Since, it is still the researcher's assumption, so she conducts a research related to singular and plural noun to know EFL students' ability in identifying both of them in paragraph.

In English grammar, nouns are commonly defined as words that refer to the name of a person, place, thing, or ideal (Altenberg, 2010, p. 3). In cognitive grammar, things are expressed as nouns, and all the nouns listed in a dictionary denote types of things. For example, the noun tree denotes the thing "tree" as a type (Gunter, 2007, p. 64).

Rodney $(2005$, p. 83) defines that noun is a grammatically distinct category of words which includes those denoting all kinds of physical object, such as persons, animals and inanimate objects. John (2002, pp. 175-176) adds, nouns are words like cup, democracy, game, driver, Chicago. They do not have special endings to show that they are nouns, or to show that they are subject or object. Nouns have many different kinds of meaning, like refer to things, ideas and quality, action and events, and name.

According to Barbara (2007, p. 22), the word "noun" comes from Latin nomen meaning 'name'. A noun is the name of a thing. Everything that exists has a name, whether you can see it or not. A blind person cannot see something, but that does not mean that it is not there! It may only exist in our minds, like hope, beauty or calories.

Christine (2008, p. 15) states that there are many different types of nouns and many ways to use them, it what make nouns more complicated. Nouns are classes of nouns such as common, proper, concrete, abstract, and collective. Nouns are also grouped by number, gender, case categories. Numbers nouns are singular, plural, compound and collective. Gender nouns are feminine, masculine, neuter, or indefinite. To add to the confusion, nouns can be used as subjects, predicates, possessives, and objectives. Oddly enough, some nouns are verbs (action words). However, when an -ing is added to the end of the verb, these words can be used as noun and they are called gerunds.

In English language, nouns are inflected for grammatical numbers, the singular and the plural. The singular nouns are words which indicate someone is speaking of one or single thing. While plural nouns are words which indicate someone is speaking of more than one certain number of things. Whereas Jean (2001, p. 3) suggests nouns can be singular, referring to one thing, or plural, referring to more than one thing. Nouns can be possessive as well; possessive nouns indicate ownership or close relationship. Regardless of the type, nouns should always agree with their verbs in sentences; use singular verbs with singular nouns and plural verbs with plural nouns. You have to know how a noun works in order to write an effective sentence.

There are several types of nouns used to make up a sentence in the English language which grammarians have developed a whole series of noun types, namely:

1. Proper Nouns

Wariner (1982, p. 37) defines that a 
proper noun names a particular person, place or thing. It is always begun with a capital letter, since the noun represents the name of a specific person, place, or thing. The names of days of the week, months, historical documents, institutions, organizations, religions, their holy texts and their adherents are proper nouns. A proper noun is the opposite of a common noun. As opposed to proper noun, all other nouns are classified as common nouns (e.g. document, mayor, girl, desert, country, people).

2. Common Nouns

A common noun is a noun referring to a person, place, or thing in a general sense -usually, people should write it with a capital letter only when it begins a sentence. A common noun is the opposite of a proper noun.

3. Concrete Nouns

A concrete noun is a noun which names anything (or anyone) that people can perceive through their physical senses: touch, sight, taste, hearing, or smell. A concrete noun is the opposite of an abstract noun.

4. Abstract Nouns

An abstract noun is a noun which names anything which people can not perceive through their five physical senses, and is the opposite of a concrete noun.

5. Countable Nouns

A countable noun (or count noun) is a noun with both a singular and a plural form, and it names anything (or anyone) that people can count. We can make a countable noun plural and attach it to a plural verb in a sentence. Countable nouns are the opposite of non-countable nouns and collective nouns.

6. Non-countable Nouns

There are other nouns that typically are not counted; they are called, also appropriately, non-count nouns" (Altenberg, 2010, p. 14). A non-countable noun (or mass noun) is a noun which does not have a plural form, and which refers to something that people could (or would) not usually count. A noncountable noun always takes a singular verb in a sentence. Non-countable nouns are similar to collective nouns, and are the opposite of countable nouns.

\section{Collective Nouns}

According to Werner (2002, p. 77) collective Nouns are nouns that refer to a group of people, animals, things, and so on as a unit. A collective noun is similar to a non-countable noun, and is roughly the opposite of a countable noun. Collective nouns are singular when we think of them as groups and plural when we think of the individuals acting within the whole (which happens sometimes, but not often). Collective nouns are count nouns, which mean they can be pluralized: a university has several athletic teams and classes; the immigrant families kept watch over their herds and flocks; all the committees have now made their recommendations.

According to Binsar (2007, p. 171), singular noun is a single unit or one of count nouns which some are written or spelled differently compare to the same noun which is more than one unit. Jean (2006, p. 29) adds that a singular noun names one person, animal, place, thing, or abstraction.

Table 1. Singular Noun

\begin{tabular}{cccc}
\hline Person & Place & Thing & $\begin{array}{c}\text { Abstrac- } \\
\text { tion }\end{array}$ \\
\hline Girl & Town & House & Idea \\
\hline Boy & Airport & Piano & Science \\
\hline Doctor & Area & Radio & Problem \\
\hline
\end{tabular}

1. To use a singular noun, there are 2 ways: Always use a noun determiner (a/an, the, one, this, that, any, each, every, another, either, neither, my, yours, his, her, our, 
their, or a possessive noun)

2. Use a singular verb (he/she/it/ form)

Example

Table 2. Plural Noun

\begin{tabular}{ccc}
\hline $\begin{array}{c}\text { Noun Deter- } \\
\text { miner }\end{array}$ & $\begin{array}{c}\text { Singular } \\
\text { Noun }\end{array}$ & $\begin{array}{c}\text { Singular } \\
\text { Verb }\end{array}$ \\
\hline A & Book & Is \\
\hline The & Book & Has \\
\hline My & Bokk & Weighs \\
\hline My & Team & Wins \\
\hline A & Family & Has \\
\hline The & Class & Is \\
\hline
\end{tabular}

According to Jean (2006, p. 30) a plural noun names or two or more people, animals, places, things, or abstractions. Christine (2008, p. 20) says plural nouns name more than one person, place, or idea. In English, the formation of plurals is simpler than many other. Sitompul (2007, p. 1) plural noun consists of two kinds, namely regular plural form and irregular plural noun.

1. Regular Plural Form

a) To make most plural nouns, add $-\mathrm{s}$

One bird two birds

One street two streets

One rose two roses

b) Add $-e s$ to nouns ending in $-s h,-c h$, $-s s$, and $-x$

One dish two dishes

One match two matches

One class two classes

One box two boxes

c) If a noun ends in a consonant $+-y$, change the $y$ to $i$ and add $-e s$, as in, if $-y$ is preceded by a vowel, add only $-s$, as in.

One baby two babies

One city two cities

One toy two toys

One key two keys
2. Irregular Plural Form

a) If a noun ends in $-f e$ or $-f$, change the ending to -ves. (exceptions: beliefs, chiefs, roofs, cuffs, cliffs.)

One knife

two knives

One shelf two shelves

b) The plural form of nouns that end in $-o$ is sometimes -oes and sometimes -os.

One tomato two tomatoes

One zoo two zoos

One zero two zeroes/zeros

c) There is some irregular plural form that should be memorized.

$\begin{array}{ll}\text { A man } & \text { two men } \\ \text { A woman } & \text { five women } \\ \text { A tooth } & \text { four teeth } \\ \text { A foot } & \text { six feet } \\ \text { A goose } & \text { two geese } \\ \text { A mouse } & \text { five mice } \\ \text { A louse } & \text { four lice } \\ \text { A child } & \text { two children } \\ \text { An ox } & \text { two oxen }\end{array}$

d) Add -s to compound nouns

A looker-on two lookers-on

A passer-by four passers-by

e) The plural form of some nouns is the same as the singular form.

One sheep two sheep

One deer five deer

f) There are some plural nouns but seen singular. It do not have singular form.

Cattle, People, etc.

g) The names for field of science are always in plural form, although a means of singular.

Politics, ethics, physics, metaphysics, mathematics, etc.

h) The names for field of science are always in plural form, although a means of singular. The plural form is in a pair.

Shoes a pair of shoes

Sandals a pair of sandals

Trousers a pair of trousers

Scissors 
Spectacles a pair of spectacles

A paragraph is a basic unit of organization in writing in which a group of related sentence develops one main idea. A paragraph can be as short as one sentence or as long as ten sentences. The number of sentence in unimportant; however, the paragraph should be long enough to develop the main idea clearly. A paragraph may stand by itself. A paragraph may also be one part of a longer piece of writing such as chapter of a book or essay. A paragraph has three major structural parts: topic sentence, supporting sentence, and a concluding sentence. (Oshima, 1999).

Regina (2002, p. 13) defines paragraph is as a group of sentences that develops one main idea; in other word, a paragraph develops a topic. A topic is the subject of the paragraph; it is what the paragraph is about. Whereas, Sarada (2006, p. 1) suggests that a paragraph is not a mere set of sentences put together one after another. Just as a sentence has a particular structure like subject and verb etc., so also a paragraph.

In writing a research, it is needed some formulations of the problems to guide the research. Therefore, the problem that is going to be discussed in this research was as follow: How is the students' ability to identify singular and plural noun in paragraph at second semester students of English Department in Putera Batam?

\section{Method}

\section{Research Design}

The design of this research is descriptive. Descriptive studies are those which are concerned with describing the characteristics of a particular individual, or of a group (Kothari, 2004). In this research, the researchers describe the students' ability to identify singular and plural nouns in paragraph at second semester students of English Department in Putera Batam University. Population and Sample
The population of this research is the second semester students of English Department in Putera Batam University. They consists of three classes with total number of population was a hundred and fifty students. It is complicated if the researcher conducts the research from the whole population. Therefore, Cohen (2007, p. 100) said it needs to obtain data from a smaller group or subset of the total population in such a way that that the knowledge gained is representative of the total population under study. Thus smaller group is the sample. In descriptive research, the sample size is normally $10 \%$, but for smaller population $20 \%$ may be required. So that, researcher used simple random sampling and take forty students of a hundred and fifty students to be the sample of the research

\section{Procedure}

The researchers collect the data through some procedure as follows:

1. Decide the items test based on the syllabus.

2. Do the try out to get reliability of the test

3. Analyze the try out result.

4. Repair the test which would be given

5. Conduct the test to the students.

6. Collect the test.

7. Analyze the test result.

\section{Instrument}

Validity of the Test

Validity shows whether an instrument is valid. The test will be valid if it measure what it is supposed to measure. Arikunto (2010: 86) In this study, the validity of each item is calculated using the product moment formula:

$$
R_{x y}=\frac{N\left(\sum x y\right)-\left(\sum x\right)\left(\sum y\right)}{\sqrt{\left\{N \sum x^{2}-\left(\sum x\right)^{2}\right\}\left\{N \sum y^{2}-\left(\sum y\right)^{2}\right\}}}
$$

\section{Where:}

Rxy = Coefficient of correlation between $\mathrm{x}$ and $y$ variable or validity of each item 
ELLITE $\mid \begin{aligned} & \text { Journal of English Language, } \\ & \text { Literature, and Teaching }\end{aligned}$

$\mathrm{N}=$ The number of students/subject participating in the test

$\Sigma \mathrm{x} \quad=$ The sum of score in each item

$\Sigma \mathrm{x} 2=$ The sum of the square score in each item

$\Sigma y \quad=$ The sum of total score from each student

$\Sigma y 2=$ The sum of the square score from each student

$\Sigma x y=$ Thes um of multiple of score from each student with the total score in each item

Reliability of the Test

To find out the reliability the test, the researcher uses split-half method and finds the correlation coefficient by using Pearson Product Moment formula. Variable $\mathrm{x}$ for the total correct answers from items with odd numbers and the variable $y$ for the total correct answer from the even numbers. Arikunto (2010: 95) states the formula as follows:

$$
R_{x y}=\frac{N\left(\sum x y\right)-\left(\sum x\right)\left(\sum y\right)}{\sqrt{\left\{N \sum x^{2}-\left(\sum x\right)^{2}\right\}\left\{N \sum y^{2}-\left(\sum y\right)^{2}\right\}}}
$$

Where:

$\mathrm{Y}=$ the even number test

$\mathrm{R}=$ the correlation coefficient between variable $x$ and $y$

$\mathrm{X}=$ the odd number test

$\mathrm{N}=$ the total number of teste

$\Sigma x y=$ the total scores of cross product $\mathrm{xy}$

Then, the researcher analyzed the $r$-value by using Spearman-Brown's formula (Arikunto, 2010). The formula is as follows.

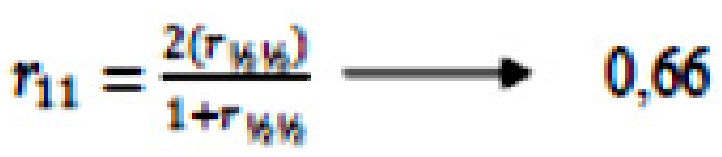

Where:

R11= Thecorrelation coefficient between variable $\mathrm{x}$ and $\mathrm{y}$

$\mathrm{r}^{1 / 2} \frac{1}{2}=$ Theodd number test

Reliability Categories:

$$
\begin{array}{ll}
0.81-1.00 & =\text { very high } \\
0.61-0.80 & =\text { high } \\
0.41-0.60 & =\text { enough }
\end{array}
$$

$$
\begin{array}{ll}
0.21-0.40 & =\text { low } \\
<0.20 & =\text { very low }
\end{array}
$$

The instrument that had been used to collect the data in this research is grammar test. The test is in the form of multiple choices and essay that must be based on the some paragraphs and the students is given about 60 minutes to do that. The researcher will prepare 30 items with 3 paragraphs.

In analyzing the data, the researcher found the students' score: calculates students' score, calculate mean and determine students' achievement categorization. The researcher gives the score for the students' work based on the correct answer that the students make by using the following formula by Arikunto (2010, p. 235):

\section{SCORE $=\frac{\text { Number of correc } t \text { an swer }}{\text { Number of items tested }} \times 100$}

$$
M=\frac{\sum X}{N}
$$

Where:

$$
\begin{array}{ll}
\mathrm{M} & =\text { Mean } \\
\Sigma \mathrm{X} & =\text { Total score of the students } \\
\mathrm{N} & =\text { Number of the sample }
\end{array}
$$

The measurement of the students' achievement was interpreted as follows:

Table 3. Classification or Categorization of students' achievement

\begin{tabular}{cc}
\hline Criteria of Mastery & Grade \\
\hline $91-100$ & $91-100$ \\
\hline $81-90$ & $81-90$ \\
\hline $71-80$ & $71-80$ \\
\hline $61-70$ & $61-70$ \\
\hline $51-60$ & $51-60$ \\
\hline Less than 50 & Less than 50 \\
\hline
\end{tabular}

\section{Result and Discussion}

It was obtained that from 30 test items; 
there are 21 test items which were valid and 9 test items which are invalid. They are on number $1,5,6,9,12,14,18,24$ and 25 . They were to be said invalid with the reasons the calculation result of their value (the correlation of score each item) was lower than the r table value.

The following was the example of item validity calculation for item number 1 , and for the other items would use the same formula. The result of calculation on validity of the item (with 19 correct answers). In addition, the students' ability to identify singular nouns in paragraph was fair, it can be seen from the mean score 70 that the range is 61-70.

Then the researcher analyzed the score to find out the ability of each student, it mean how many students excellent, very good, good, fair, poor, and very poor to identify of singular nouns in paragraph. The students' scores were put in the classification as shown in the tables bellow:

Table 4. The Classification of the Students' Ability to Identify Singular Nouns in Paragraph

\begin{tabular}{|c|c|c|c|}
\hline Criteria of Mastery & Grade & Frequency & Percentage \\
\hline 91-100 & Excellent & 2 & $5 \%$ \\
\hline $81-90$ & Very Good & 13 & $32.5 \%$ \\
\hline $71-80$ & Good & 8 & $20 \%$ \\
\hline $61-70$ & Fair & 8 & $20 \%$ \\
\hline $51-60$ & Poor & 3 & $7.5 \%$ \\
\hline Less than 50 & Very Poor & 6 & $15 \%$ \\
\hline \multicolumn{2}{|c|}{ Total } & 40 & $100 \%$ \\
\hline
\end{tabular}

number 1 was 0.255 . After that the researcher consulted the result to the table of $r$ product moment with the number of subjects $(\mathrm{N})=$ 40 and significance level $5 \%$ it is 0.312 . Since the result of the calculation was lower than $r$ table, the index of validity of the item number 1 is considered to be invalid.

A good test must be valid and reliable. Besides the index of validity, the writer calculated the reliability of the test using Pearson Product Moment and itwas continued by using Spearman-Browns' formula by Arikunto (2005, p. 95).

From the calculation, it was found out that $\mathrm{r} 11$ (the total of reliability test) was 0.66 , it means the reliability was high because in range 0.61-0.80.

After the scores for students' answer were checked, the researcher found that the lowest score for the ability of the students' singular noun in paragraph was 11 (with 2 correct answers), the highest score was 100
The table above shows that 2 students or $5 \%$ were categorized excellent, 13 students or $32.5 \%$ were categorized into very good, 8 students or $20 \%$ were categorized into good, 8 students or $20 \%$ were categorized into fair, 3 students or $7.5 \%$ were categorized into poor, and 6 students or $15 \%$ were categorized into very poor.

Then, the students' result of Plural Nouns could be seen in. After the scores for students' answer were checked, the researcher found that the lowest score for the ability of the students' singular noun in paragraph was 18 (with 2 correct answers), the highest score was 100 (with 11 correct answers). In addition, the students' ability to identify plural nouns in paragraph was good, it can be seen from the mean score 73 that the range is $71-80$.

Then the researcher analyzed the score to find out the ability of each student, it means how many students excellent, very good, good, fair, poor, and very poor to identify of singular 
nouns in paragraph. The students' scores were put in the classification as shown in the tables bellow:
23,33 (with 7 correct answers), the highest score was 96,67 (with 29 correct answers).

Table 5. The Classification of the Students' Ability to Identify Plural Nouns in Paragraph

\begin{tabular}{cccc}
\hline Criteria of Mastery & Grade & Frequency & Percentage \\
\hline $91-100$ & Excellent & 12 & $30 \%$ \\
\hline $81-90$ & Very Good & 8 & $20 \%$ \\
\hline $71-80$ & Good & 4 & $10 \%$ \\
\hline $61-70$ & Fair & 10 & $25 \%$ \\
\hline $51-60$ & Poor & 3 & $7.5 \%$ \\
\hline Less than 50 & Very Poor & 3 & $7.5 \%$ \\
\hline & & 40 & $100 \%$ \\
\hline
\end{tabular}

The table above showed that was 12 students or $30 \%$ were categorized excellent, 8 students or $20 \%$ were categorized into very good, 4 students or $10 \%$ were categorized into good, 10 students or $25 \%$ were categorized into fair, 3 students or $7.5 \%$ were categorized into poor, and 6 students or $7.5 \%$ were categorized into very poor.

Furthermore, in measuring the students' ability to use singular and plural noun in paragraph, the researcher counted the students'
In addition, the students' ability to identify singular nouns in paragraph was good, it can be seen from the mean score 71,08 that the range is $71-80$.

Then the researcher analyzed the score to find out the ability of each student, it mean how many students excellent, very good, good, fair, poor, and very poor to identify of singular and plural nouns in paragraph. The students' scores were put in the classification as shown in the tables bellow:

Table 6. The Classification of the Students' Ability to

Identify Singular and Plural Noun in Paragraph

\begin{tabular}{|c|c|c|c|}
\hline Criteria of Mastery & Grade & Frequency & Percentage \\
\hline $91-100$ & Excellent & 3 & $7.5 \%$ \\
\hline $81-90$ & Very Good & 10 & $25 \%$ \\
\hline $71-80$ & Good & 11 & $27.5 \%$ \\
\hline $61-70$ & Fair & 6 & $15 \%$ \\
\hline $51-60$ & Poor & 5 & $12.5 \%$ \\
\hline Less than 50 & Very Poor & 5 & $12.5 \%$ \\
\hline \multicolumn{2}{|c|}{ Total } & 40 & $100 \%$ \\
\hline
\end{tabular}

score. After the scores for students' answer were checked, the researcher found that the lowest score for the ability of the students' singular and plural nouns in paragraph was
The table above showed that was 3 students or $7.5 \%$ were categorized excellent, 10 students or $25 \%$ were categorized into very good, 11 students or $27.5 \%$ were categorized 
into good, 6 students or $15 \%$ were categorized into fair, 5 students or $12.5 \%$ were categorized into poor, and 5 students or $12.5 \%$ were categorized into very poor.

In general, the data showed that the students' ability to identify singular and plural noun in paragraph was good. It can be seen from the mean score 71,08 that the range is 71-80. In addition, based on the result of the test, it showed that was 3 students or $7.5 \%$ were categorized excellent, 10 students or $25 \%$ were categorized into very good, 11 students or $27.5 \%$ were categorized into good, 6 students or $15 \%$ were categorized into fair, 5 students or $12.5 \%$ were categorized into poor, and 5 students or $12.5 \%$ were categorized into very poor.

The problems might be caused by the following reason:

For example:

1. Some students cannot identify whether singular and plural noun that should be used for the answer of the questions given although the researcher gave the sign of singular and plural noun by given article a/an

(Multiple choice answer)

Question: We went there by a .......... First we left home at 4 P.M.
a. Motorcycle
b. Motorcycles
c. Motorcicles
d. The motorcycle

Students' answer: d. The Motorcycle

The correct answer: a. Motorcycle

2. Some of students were incorrect to change singular noun which has ending $-\mathrm{y}$.

(Changing word)

Paragraph : ......Because she has a beautiful character and beauty physical, many people love her.......

Students' answer :beautys

The correct answer : beauties

3. Some students cannot determine and grouped the collective noun into singular noun, moreover they grouped the collective noun into plural noun.

Paragraph: .....They are my friends and my family .......

Students' answer:

My family $\rightarrow$ plural noun

The correct answer:

My family $\rightarrow$ singular noun

\section{Conclusion}

After interpreting the result of data analysis, the researchers draw a conclusion that students' ability at second semester students of English Department in Putera Batam University in identifying singular and plural noun in paragraph are categorized into good. Based on the result data were 3 students or $7.5 \%$ were categorized excellent, 10 students or $25 \%$ were categorized into very good, 11 students or $27.5 \%$ were categorized into good, 6 students or $15 \%$ were categorized into fair, 5 students or $12.5 \%$ were categorized into poor, and 5 students or $12.5 \%$ were categorized into very poor. Besides that, the students' ability to identify singular nouns in paragraph was fair and the students' ability to identify plural nouns in paragraph was good.

\section{References}

Altenberg, Evelyn P. and Robert M. Vago. (2010). English Grammar; Understanding them Basics, New York: Cambridge University Press.

Arikunto, Suharsimi. (2010). Dasar-Dasar Evaluasi Pendidikan. Jakarta: Bumi Aksara.

Azar, Betty Scrampter. (2003). Fundamentals of English Grammar (3nd ed). New York: Longman.

Cohen, Louis, et al. (2007). Research Methods in Education. New York: Routledge.

Djauhari, Imam D. (1988). Mastery on English 
Grammar. Surabaya: Indah.

Dykes, Barbara. (2007). Grammar for Everyone. Victoria: ACER Press.

Eastwood, John. (2002). Oxford Guide to English Grammar. Oxford: Oxford University Press.

Eggenschwiler, Jean. (2001). Writing: Grammar, Usage, and Style. New York: Hungry Minds, Inc.

Heaton, J. B. (1990). Writing English Language Testing. London: Longman.

Huddleston Rodney \& Pullum, K, Geoffrey. (2005). A Student's Introduction to English Grammar. Cambridge: Cambridge University Press.

Kothari, R. C. (2004). Research Methodology (Methods and Techniques). New Delhi: New Age International Ltd.

Lacie, Christine. (2008). Barron's English for Foreign Language Speakers: the Easy Way. New York: Barron's Educational Series, Inc.

Radden, Gunter \& Dirven, Rene. (2007). Cognitive English Grammar. Philadelphia: John Benjamins Publishing Company.

Sarada, M. (2006). Paragraph to Essay Writing: Advanced Writing Skills in English. New Delhi: Sterling Publisher Ltd.

Schatz, S, Mary. (2002). Grammar Rules for Students, Parents \& Teachers A Straightforward Approach to Basic English Grammar and Writing Skills. Bloomington: Garlic Press.

Sitompul, Jonggi. (2003). English Grammar for Beginner. Jakarta: Gramedia.

Sihombing, Binsar. (2007). English Grammar Comprehension. Jakarta: Grasindo.

Warriner, John E. (1982). English Grammar and Composition; First Course, New York: Harcourt Brace Jovanovich Publishers.

Werner, Patricia K. and John P. Nelson. (2002).
Mosaic 2 Grammar, 4th Edition, New York: McGraw-Hill Companies, Inc.

Yates, Jean. (2006). Master the Basic: English. New York: Barron's Educational Series 